\title{
The Mujaddid of His Age: Al-Ghazali And His Inner Spiritual Journey
}

\author{
Mohd Rosmizi, ${ }^{\mathrm{a}, *}$ Salih Yucel ${ }^{\mathrm{b}}$, \\ ${ }^{a}$ Lecturer at Faculty of Leadership and Management (FKP), Islamic Science University of Malaysia (USIM). \\ ${ }^{a}$ Research Associate at Islamic Science Institute, Islamic Science University of Malaysia (USIM). \\ ${ }^{b}$ Associate Professor, Lecturer and Course Director, Centre for Islamic Studies and Civilisation and member of Public and \\ Contextual Theology Research Centre, Charles Sturt University, Australia. \\ *Corresponding author: rosmizi@usim.edu.my
}

\begin{abstract}
Article history
Received: 2015-06-01

Received in revised form: 2016-03-07

Accepted: 2016-03-09

Abstract

Imam al-Ghazali has been regarded as the mujaddid (the reviver or the Islamic reformer) of the 5th century AH of Islam, and has been credited with various titles, of which the most famous is as Hujjat al-Islam (Proof of Islam). This article investigates the development of al-Ghazali's thought and spiritual journey through different stages of his life. Employing library research and historical analysis, this article divides al-Ghazali's life into three main periods, namely, before, during, and after seclusion. Initially he was mainly jurist and theologian, but radically transformed to become a personal Sufi during the seclusion period, leading to his subsequently becoming an active public Sufi. The result from the analysis of the first phase of al-Ghazali's life shows that al-Ghazali experienced a radical spiritual and intellectual transformation, which led him to discover Sufism, but without neglecting theology, jurisprudence, and philosophy. There was significant evolution in al-Ghazali's life towards a spiritual orientation as shown by the analysis of his second phase, in which he later sought to share with others after seclusion. If in the phase of seclusion al-Ghazali was personal-namely, focused on personal reformation, devotion, and inner spiritual self - the phase of al-Ghazali's life after seclusion marked the beginning of an active spiritual public life. The result shows that this new al-Ghazali actively tried to reform every class of society (the public, elites, theologians, philosophers, mystics, and others) through teachings, writings, and by sharing his personal spiritual experience. It is evident that with all his efforts and achievements, al-Ghazali offered a great and abiding contribution in reviving the spiritual dimension of Islam, furnished and served it to the Muslim world.
\end{abstract}

Keywords: al-Ghazali, the first phase, before seclusion, the second phase, during seclusion, the third phase, after seclusion, personal Sufi, public Sufi 


\subsection{INTRODUCTION TO AL-GHAZALI}

Al-Ghazali (450-505H / 1058-1111) was one of the most distinguished scholars of his time, whose life was transformed by the experience of spiritual crisis and a desire to respond to what he perceived as erroneous interpretations and practices against Islamic orthodoxy. His works demonstrate that his knowledge and understanding encompass not just the religious sciences, but the general sciences of his time. He was well-versed in the various fields of knowledge and was acutely aware of the social, intellectual and spiritual issues of his era. Al-Ghazali's work is not dissimilar to Said Nursi's (1987-1960) Risale-i Nur. Nursi stated that his work, a product of "the lights, which proceed from the Qur'an, are not only scholarly matters pertaining to the intellect, they are rather matters of belief which pertain to the heart, the spirit and spiritual states. They resemble the most elevated and valuable knowledge of God" (Nursi, 1996, 420). Similarly, it can be argued that the works of al-Ghazali are the outcomes of an enlightened aql with the Qur'an, reflections of the heart purified with dhikr, and a soul elevated through sincerity. Through his spiritual experiences and difficulties, al-Ghazali was given the direct knowledge of God ('ilm laduni).

Having deep and comprehensive understanding of the spiritual states and abilities of human means that he knew well the obstacles to spiritual progress and able to put forth solutions not only in theory, but also in practice. He laid the foundation to reconcile philosophy, Islamic theology and Sufism. He was not reactionary opponent of philosophy like some Muslim scholars of his time, nor was he a passive receiver of it. Indeed, al-Ghazali only refuted the parts of philosophy which were considered harmful or misguided and did not refute those which benefited spiritual beings.

His major work, Ihya' 'Ulum al-Din influences various fields (e.g., theology, jurisprudence, Sufism, ethics, etc.) more than any other works in the history of Islam. His works were accepted as an undisputed authority in the field (Gulen, 2011b, 22) after the Qur'an and hadith. Indeed, his works are not only regarded as books, but also as a series of renewal of Islamic thought. They advance people's understanding not only in general knowledge but in worship, ethics and morality, behaviour, purification of the soul and spiritually destructive acts and conditions.

Al-Ghazali is historically unique. There is no known scholar in Islamic history who could produce works in various fields that influenced the Muslim and the Western world to such an extent. He looked deeply into the problems of the Muslims during his time and analysed them intensely before proposing solutions. He became a master teacher with generations of scholars including exegetes, theologians, philosophers as well as mystics, turn to his works. His works influence more than fifty Western scholars (Griffel, 2014) who focus more in internal issues and causes and to seek solutions through internal change.

In order to understand al-Ghazali's works, it is necessary to examine his life and religious practice as they offer important and various insights into his work. Al-Ghazali wrote with a mind enlightened by deep knowledge of the Qur'an and Hadith, a heart purified by tears of suffering and repentance, a soul strengthened by the fulfilment of intense religious worship and remembrance of God at late hours in the night and a spirit freed with the wings of sincerity.

\subsection{THE BACKGROUND OF AL-GHAZALI'S SPIRITUAL JOURNEY}

Having studied in north-eastern Persia under al-Juwayni (the most famous theologian of his time), al-Ghazali's scholarship captured the attention of the Seljuk vizier, Nizam al-Mulk, who appointed him as chief professor in the Nizamiyyah college of Baghdad. A spiritual crisis, however, led him to renounce his worldly possessions and seclude himself from public life. Al-Ghazali was living in seclusion for 11 years (1095-1106). Scholars divide al-Ghazali's life into different categories. For instance, MacDonald divides it into two main parts (before conversion and after conversion); alHourani divides it into four periods (an early period, a period of retirement, after coming out from retirement, and a final retirement); and Muhammad Hozien divides it into three phases (the phase of learning and education, the career life, and the phase of retirement until death) (see MacDonald, 1899; Hourani, 1984, and http://www.ghazali.org/index.html). Nevertheless, the development of 
his thought and spiritual journey can be divided into three main periods, namely, before, during, and after seclusion. This division of three main periods of al-Ghazali's life is based on different radical development of al-Ghazali's thought and spiritual journey that relate to his periods of seclusion, namely before, during and after seclusion. Al-Ghazali's thought and spiritual journey evolved radically through these three different stages. Initially he was mainly jurist and theologian before seclusion, but radically transformed to become a personal Sufi during the seclusion period, leading to his subsequently becoming an active public Sufi after the seclusion period. There was significant evolution towards a spiritual orientation in the second phase that he later sought to share with others after seclusion. Because of that, it is appropriate to analyse the development of alGhazali's thought and spiritual journey based on these three different periods related to his seclusion (before, during and after seclusion).

There were several primary reasons for al-Ghazali's critical stance and withdrawal from worldly affairs for a spiritual life. The imbalance between mind (reason) and heart (spirituality), and between outward and inward observance of religious life among Muslim society provided the axis of these motivations. In addition, his mystical goal of attaining closeness (taqarrub) to God leading to spiritual union with Him also serves as another factor. He passionately advised readers to observe the inner dimension of religious observance in order to achieve a higher spiritual state promising real eternal happiness. He perceived his time as coloured by many potentially arid and even misleading interpretations and practices. He saw the faith of various classes of people as becoming weak, religious observance as deprived of spirituality, with much erroneous philosophy widespread. He believed that the overall condition of his time was corrupt and stagnant, and that these problems had spread to all levels of people, from laymen to the elite, from jurists and theologians to philosophers and mystics. He observed that this serious sickness "has become general, the doctors have fallen ill, and mankind has reached the verge of destruction" (al-Ghazali 1967, 120-121; Deliverance, 2004, 80).

Al-Ghazali considered the most noticeable lack among various groups of people was in the observance of any inner dimension, or spiritual element of good deeds. He realised that there were some groups who claimed to teach the real essence of Islam, such as mystics and certain esoteric movements, in particular as represented by the Batinites. However, he held that these people were not free from what he saw as erroneous beliefs and practices. Some mystics claimed that they were no longer in need of formal worship. In addition, they focused too much on the heart (spirituality) and ignored the importance of the mind (reason). The philosophers, on the other hand, depended much on the mind (reason), ignoring the importance of the heart (spirituality). Esoteric movements, such as the Batinites who claimed to teach the spiritual dimension, had distorted the fundamental teachings of Islam under the veil of spirituality. Al-Ghazali argued that their teachings were full of distortions and contradictions, ignoring and rejecting the established external meaning and outward observance of good deeds. In addition, he also argued that most theologians and other scholars were not free from taqlid (naïve belief or blind following the view and authority of others), the majority only emphasising the outer dimension of good deeds. Al-Ghazali believed that all of these problems had weakened faith and made Muslim conditions stagnate (al-Ghazali, 1967, 117-131, 69-99; 2004, 76-92, 26-56), and therefore, "a complete overhaul was needed," (Qayyum, 1992, 15).

\subsection{THE FIRST PHASE: BEFORE SECLUSION}

During his early career (until 1095), al-Ghazali mastered several subjects, such as 'ilm al-kalam (theology), fiqh and usul al-fiqh (jurisprudence and principles of jurisprudence), and philosophy. He was also asked by the Abbasid ruler of Baghdad to write against Isma'ilism or Batinism, a Shi'ite sect. Although he wrote several books on fiqh which address different kinds of good deeds (e.g., devotional acts, such as prayer, almsgiving, etc.), there is not much difference between his approach and that of jurists, both of the past and of his own time, in that they focus on the details of the outer dimension of the subjects. The difference is that his treatments of the subjects are much more extensive and profound, as evident from his works al-Wasit fi al-Madhhab (The Medium [digest] in the [Jurisprudential] School) and al-Wajiz fi Fiqh al-Imam al-Shafi'i (The Condensed 
in Imam al-Shafi' $i$ Jurisprudence) (al-Ghazali, 1997b). In both of these works, especially al-Wasit, al-Ghazali explains various issues in great detail concerning different kinds of prescribed devotional acts, mainly related to formal outward observance.

As Hourani observed, although al-Ghazali already studied and began to have some interest in Sufism at this time, he had not devoted any writing to it (Hourani, 1984, 291). As he relates in Munqidh (his autobiographical account), this was mainly because in addition to his teaching activity he was concerned with searching for necessary truths by scrutinising various sects and teachings, but he had not yet started to practise Sufism (al-Ghazali, 1967, 60-64, 69-109; 2004, 17 $20,26-66)$. Within this time he produced several great works on scrutinising and refuting the Batinites and the philosophers. For instance, on the Batinites, he wrote (in 1092 CE) Fada'ih alBatiniyyah wa Fadail al-Mustazhiriyyah (The Infamies of the Batinites and the Merits of the Mustazhirites), and in 1094 and 1095 CE he completed two important works on philosophy, namely, Maqasid al-Falasifah (The Aims of the Philosophers) and Tahafut al-Falasifah (The Incoherence of the Philosophers) (See Maqasid al-Falasifah, 2000; and The Incoherence of the Philosophers. The former is to explain their fundamental views, and the latter is to refute their errors.). In addition, al-Ghazali also wrote several other important works on theology and philosophy (for a complrehensive chronology of al-Ghazali's writings, see Hourani, 1984). In a book known as Mizan al-'Amal (Criterion of Action), written in his last year in Baghdad (1095 $\mathrm{CE}$ ) before his withdrawal from the worldly life, he did praise Sufism. Although it emphasises that apart from knowledge ('ilm), action ('amal) is required for happiness, its discussion is more theoretical and philosophical, and its central focus is more on ethics, or rather philosophical ethics (for an analysis of al-Ghazali's theory of ethics, see Quasem, 1978; Umaruddin, 1996, etc.).

In order to find the truth, al-Ghazali classified all the sects and movements in his time into four main categories, namely, the theologians (mutakallimun), the Batinites (the Batiniyyah), the philosophers, and the Sufis (mystics), all groups that he called the "seekers after truth," (al-Ghazali, $1967,69 ; 2004,26)$. He strongly believed that the truth could not lie outside these groups. Part of the focus of his investigation was the performance of good deeds and the observance of religious Law. He discovered that there were gaps, imbalances, and a lack of spiritual elements among various classes of these seekers in particular, and within the society in general. He observed that there was an imbalance between mind (reason) and heart (spirituality), or between outer and inner aspects of religious observance among the philosophers, mystics, theologians, and the public.

Al-Ghazali became convinced that the socio-religious conditions of his time needed to be renewed. But he also realised that he himself was lacking in spirituality and did not yet know the best way to implement such a reformation. Indeed, he himself was still searching for the necessary truths that could answer his questions and confusions. Thus he realised that unless he reformed himself he could not effectively reform the Muslim world (al-Ghazali 1967, 120-123; 2004, 79-83; Abdul Qayyum, 1992, vii-viii).

Finding himself destitute of necessary truths or the infallible knowledge that he had been searching for, he fell into almost total scepticism for nearly two months until being cured by God's mercy (al-Ghazali 1967, 65-68; 2004, 21-25). Within this short but critical period, he doubted all things including the infallibility of self-perception, a method subsequently used by Descartes (Ibid.; Watt, 1953 and 2004, 10). More detailed discussions of doubt and certainty in al-Ghazali can be found in Sobhi Rayan (2004), Tamara Albertini (2005), Syed Rizwan Zamir (2010) and Omar Edward Moad (2009). Later, after scrutinising the various "seekers after truth," and beginning to realise that Sufism could answer his quest and help him attain his goal, he fell into a serious inner crisis between "the attractions of worldly desires and the impulses towards eternal life" for nearly six months. This inner crisis affected his physical health seriously (al-Ghazali 1967, 102-104; 2004, 58-61). At this stage, his goal was totally spiritual and other-worldly. After earnestly seeking refuge with God and praying to Him, al-Ghazali re-gained confidence in necessary truths and managed to overcome his passion, resolving to turn himself away from the world. Al-Ghazali considered God's help as His light cast into his breast. He came to believe that things divine cannot be understood merely from rationalism and empiricism. He considered God's mercy or the light of God as "the 
key to the greater part of knowledge," and he regarded this as the first principle (al-Ghazali 1967, 67-68; 2004, 24-25). Finally, in November 1095 CE (Dhu al-Qa'adah, 488 AH), he set out for a new phase in his life, namely, one of seclusion and devotion (al-Ghazali 1967, 102-104; 2004, 5861, finding happiness through the genuine Sufism. He writes:

I learnt with certainty that it is above all the Sufis (or the mystics) who walk on the road of God; their life is the best life, their method the soundest method, their character the purest character, (al-Ghazali 1967, 106; 2004, 63). Al-Ghazali experienced a radical spiritual and intellectual transformation, which led him to discover Sufism, but without neglecting theology, jurisprudence, and philosophy. God's mercy or the light of God became the first criterion, pervading his personal journey and writings. His aim was mystical, namely to attain the ma'rifah (gnosis or the true knowledge) of God (also known as knowledge gained through direct personal experience), closeness to God, or even the spiritual union with God through direct personal experience and quest. In order to find the best way to achieve this noble aim, al-Ghazali investigated critically various methods of the different seekers after truth.

Before his seclusion, al-Ghazali's view of good deeds was not so different from previous and contemporary scholars, namely, emphasising their outer dimension. He was then mainly a jurist, theologian, and even philosopher who did not really focus on analysing the spiritual or inner dimension of good deeds. Although at the end of this phase he was already praising Sufism, it was only on the theoretical level, as he had not yet practically engaged himself in a Sufi path. Likewise, although he already recognised that the Muslim condition needed to be reformed, he was still not ready, for he realised that he was part of the situation and needed such a reformation. For these reasons, he eventually withdrew from his worldly life and situation, setting out for retirement and seclusion, where he lived the life of a Sufi, searching for the spiritual life and contemplating on the spiritual dimension of religious observance.

\subsection{THE SECOND PHASE: DURING SECLUSION}

This phase marks the most important turning point of al-Ghazali's life. It extended for almost eleven lunar years, starting from the year of his retirement or withdrawal from his luxurious life and position in Baghdad in $1095 \mathrm{CE}$, to his return to resume teaching at Nishapur, in north-eastern Persia, in 1106 CE. His spiritual journey began when he entered and remained in Damascus for two years. In this phase, he completed three Arba'ins - the 40 day period, known to the Sufis as "Chillah" or "i'tikaf" " which is considered as a period of spiritual purification (Anwarul-Haq, 1991, 10), - withdrawing into a cell, fasting during the day, eating and sleeping little during the night. He refrained from talking about worldly matters and devoted his time to worship, remembrance of God and contemplation. These seclusions opened his heart and mind to new dimensions of understanding the universe, which are reflected in his works (Gulen, 2008, 52). He devoted all of his time to reforming himself through religious and ascetic exercises, purification of his soul, improving and beautifying his character, and performing constant recollection (dhikr) of God (al-Ghazali, 1967, 105; 2004, 61-62). Although during this phase he focused wholly on the reformation of his soul and character in seclusion, and was not socially active, it was immensely productive in terms of writing. Among other texts, he produced the Ihya' 'Ulum al-Din, widely celebrated as among the greatest works of Muslim spirituality. Through this work, al-Ghazzali brought Sufism closer to the centre of Islam while gaining more followers and lovers from the general population for Sufism. In fact, no other Sufi book has influenced Muslim thoughts like his work (Gulen, 2011b, 22). He also travelled to several places, practising meditation, extensive recollection of God (dhikr) and contemplation, and intensive purification of his soul and character, among other activities.

As recorded in his autobiography, al-Ghazali claims that during this seclusion phase "things innumerable and unfathomable" were revealed to him (al-Ghazali 1967, 106; 2004, 63), and he attained various truths (al-Ghazali 1967, 115; 2004, 74). It was within this phase that he attained ma'rifah as well as the real and deep understanding of various things. His spiritual enlightenment 
included a deeper understanding of Tawhid - the principle of the absolute Oneness, primacy, and Unity of God-, the relationship between God and men, the inner or spiritual state of self and religious matters, as well as the mysteries behind them.

Al-Ghazali's theology is fundamentally Tawhidic, in being based on the notion of Tawhid. In the Ihya', al-Ghazali reminds readers that the term "Tawhid" has now been misunderstood and reduced to become equivalent to scholastic theology, which only concerns with argumentation, the arts of asking questions, and raising doubt. He argues that in reality Tawhid has several states, and at the highest state it refers to the belief that God is alone in all actions (munfarid bi al-af'al kulliha), and therefore, "all things come from God, a belief which ruled out all intermediary causes (al-asbab wa al-wasa'il)." He holds that God is the real agent of men's actions, the determining factor of good deeds, and the source of all goodness and indeed of all creatures and actions. Nothing is outside His knowledge and will, and He has full control over all things. A person who reaches this state will only see God in all creations and actions, and will devote all his life and deeds absolutely to the One and Absolute God, leading towards spiritual union with Him (al-Ghazali, 1962, 77-79; 1986, I.1, 33-34; 1999, 4-5; 1993, I.2, 110-115; IV.1, 11-12; 2001a, 146; 2003a, I.1, 22; I.5, 30; I.8, 33-34; 2010, I.1, 3-4; I.5, 14; I.8, 15-16).

Al-Ghazali admits that no man is free from sin (except prophets), and is therefore in need of God's grace. Nevertheless, he holds an optimistic view of human nature, whereby men are capable, and indeed, are encouraged to purify themselves and work for their own salvation. In fact, the constant process of purification and beautification of the soul, which indicates his optimistic view of human nature, is among his primary objectives.

Al-Ghazali presents creation as consisting of two main dimensions, namely, the physical and the spiritual, the outer and inner, or the visible and invisible. His mystical analysis of this concept can be found in his, see The Niche, $(1981,68-84)$. He sees man as consisting of the physical body (zahir) and heart or soul, which is inner (batin) and spiritual. The former belongs to 'alam mulk or 'alam al-shahadah (the visible, physical, material or phenomenal world), while the latter belongs to 'alam al-malakut (the spiritual world or the realm of the divine world) (al-Ghazali, 1986, III.1, 3-5; 1993, III.1, 7-9; 1967, 115; 2004, 74; 2010, II.5, 44; , II.6, 48-49; 2003a, II.5, 64; II.6, 6; 2001a, 3-4, 743; 1992, 2:24.). By heart he means "the real nature of his [man's] spirit which is the seat of his knowledge of God, and not the flesh and blood which he shares with the corpse and the brute beast," (al-Ghazali, 1967, 115; 2004, 74; 1986, III.1, 3-5; 1993, III.I. 7-9). It is a "subtle tenuous substance of an ethereal spiritual sort (latifah rabbaniyyah ruhaniyyah)" which is regarded as the real essence of man (al-Ghazali, 1967, III.1, 3-5; 1993, III.I. 7-9). Al-Ghazali uses different terms to refer to the inner state of man, such as qalb (heart), ruh (soul), nafs (self or spirit), and sometimes 'aql (mind or intellect). Each of these terms is given an inner meaning, referring to the soul. The heart or soul is regarded as the core and secret essence of man, man's inner dimension, the spiritual substance from God (al-Ghazali, 1967, I.1, 54-55; 1993, I.1, 58-59), the seat or grand castle of ma'rifah (al-Ghazali 2001a, 7-8; 1967, 115; 2004, 74), the king of the city (al-Ghazali, 1967, III.1, 8; 1993, I.1, 11), which is "a divine spiritual entity of great subtlety (latifah rabbaniyyah ruhaniyyah)," (al-Ghazali, 1967, III.1, 3-5; 1993, III.1, 7-9; 2001a, 12; Quasem, 1978, 44-45). In fact, al-Ghazali formulated and systematised a religious psychology of man that is still celebrated today.

Likewise, al-Ghazali believes and argues that good deeds also consist of two dimensions, namely, outer and inner. It is the inner dimension of good deeds which is the essence (Quasem, 1974, 50). He maintains that every act will produce an effect on the soul and that this effect largely depends on how an act is performed. Therefore, good deeds are only able to bring their desired effects on the soul as well as to achieve their purpose through observing balance between their outer and inner dimensions (Quasem, 1978, 47-48). Al-Ghazali's emphasis on the observance of the inner dimension of good deeds is also evident in his argument that there are mysteries and wisdoms beyond the religious observances (e.g., prayer, fasting, almsgiving, and pilgrimage. See al-Ghazali 1967, 116; 2004, 75). He maintains that the constant performance of good deeds is required at every stage of life, and by every class of believers (Quasem, 1974, 53). 
The Ihya' 'Ulum al-Din, which he wrote during this phase, encapsulates al-Ghazali's deep thought and vision for renewal (tajdid). A brief analysis of the character and architecture of the Ihya' can be found in Ormsby's book (2008, esp. Chap. 6, 111-138). The discussion of good deeds in Ihya' is different from his previous works in presenting spiritual insights and revealing some of their mysteries. Yet, al-Ghazali does not neglect the importance of reason. Although he realises the limit of reason, he resorts to it in explaining his arguments on many occasions. Thus, he balances and even unites the roles of the heart (spirituality) and the mind (reason) that were previously separated between the philosophers and mystics. He is keen to share some of his spiritual experience through his writings. He used various methods furnished with rich sources that he obtained from his encyclopaedic mind as well as through gnosis (i.e., direct knowledge gained through personal experience) and spiritual experience.

At this stage, al-Ghazali became convinced that he had already gained the answers to his quest, the solutions to the socio-religious condition of his time. He realised that he ought not to keep himself in seclusion any longer, but should help society, to share with them his answers and solutions, and thus to reform the stagnant condition of Muslims at large. After receiving what he believed as inspiration from God to tackle the social and religious problems and had consulted several wise men about it, al-Ghazali became convinced that he was the man determined for such a renewal as envisaged by Prophetic tradition (al-Ghazali 1967, 121-123; 2004, 80-83). There is a well-known Prophetic tradition that God will send a reformer at the beginning of each century. The event in question took place just before the end of the 5th century and the beginning of the 6th century AH. Al-Ghazali is generally regarded as the reformer (mujaddid) of the 5th century AH.

Seclusion produced a new al-Ghazali. Discussion of the "old" and "new" al-Ghazali, is given by Smith (1983, Chap. $1 \&$ 2). The jurist and theologian had become a practising and enlightened Sufi. Endowed with gnosis, spiritual enlightenment, and the realisation of various truths, he was then able to see the mysteries and the inner dimensions of good deeds. From this moment, alGhazali had a new intention, vision, and mission. He states:

Previously, however, I had been disseminating the knowledge by which worldly success is attained; by word and deed I had called men to it; and that had been my intention. But now I am calling men to the knowledge whereby worldly success is given up and its low position in the scale of real worth is recognized. This is now my intention, my aim, my desire, God knows that this is so. It is my earnest longing that I may make myself and others better." (Al-Ghazali 1967, 123; 2004, 82).

Spirituality and other-worldly eternal happiness were now his core concerns. At the mystical level, similar to other prominent Sufis, his goal was to attain the closeness of God, leading to the spiritual union with Him. He systematised the spiritual science which complemented conventional and religious sciences, namely, "the Science of the Way of the Afterlife ("Ilm Tariq al-Akhirah) or "the Science of the Hereafter ('Ilm al-Akhirah)." Al-Ghazali resolved to end his seclusion, heading towards society to reform its conditions.

\subsection{THE THIRD PHASE: AFTER SECLUSION}

If in the phase of seclusion al-Ghazali was personal-namely, focused on personal reformation, devotion, and inner spiritual self - the phase after seclusion marked the beginning of an active spiritual public life. It began in July, 1106 CE (Dhu al-Qa'adah, 499 AH) when he appeared from seclusion to resume teaching at Nizamiyyah College in Nishapur. However, for some reason al-Ghazali only taught briefly at Nizamiyyah College before returning to Tus where he opened his own madrasah (religious school), where he could freely share and institutionalise his noble mission according to his own way, free from any external intervention and political pressure. Among the uniqueness of al-Ghazali's madrasah is that its teaching consists of a combination of reason and heart, fiqh and tasawwuf. Some scholars regard this later event as al-Ghazali's final withdrawal or retirement, prior to his death in 1111CE. 
This new al-Ghazali actively enlightened every class of society (the public, elites, theologians, philosophers, mystics, and others) through teachings, writings, and by sharing his personal spiritual experience. He even addressed various ministers and other high administrative officers, sending them tracts and letters which contain his sincere but firm calling for repentance and to observe the spiritual dimension of the religious life (see al-Ghazali, 1992). Among his great contributions is that he was able to combine Sufism with formal religious observance, which he had previously seen as always in conflict.

Al-Ghazali was keen to institutionalise his spiritual vision and enlightenment in the Muslim world. Perhaps, one reason for his second retirement - namely, his resignation from teaching at Nizamiyyah College in Nishapur-was that he could not achieve this mission, for he was compounded within a formal institution and lacked the freedom to implement his visions in real life. He felt that there was lack of spiritual experience which he tasted during seclusion. Perhaps it was for this reason that he returned to Tus and established his own madrasah. He sought to synthesise Sufism with traditional Islam, in a way that was understandable and practicable by various classes of people. This was, Quasem argues, the culmination of the endeavours of some previous great Sufis, such as al-Muhasibi (781-857 CE) and al-Makki (d. 996 CE) of the 9-10th century (Quasem, 1974, 48, 51). Since al-Ghazali was able to develop, systematise, and complete the various endeavours of other previous scholars, Yasien Mohamed regards him as "the great systemiser," (Yasien Mohamed, 2011, 657).

With al-Ghazali's achievement also, good deeds - as well as Islam at large-was freed from dogmatism and "formalism of scholastic literalism," as he breathed into them what has been called "the warmth of the living spirit," (Faris, 1942, 50). Al-Akiti observes that al-Ghazali was able to: balance the pursuit of the middle way with respect to everything he encountered...delicately balancing the various disciplines and traditions...and...intricately weaving together the different dimensions of Islam - the outer as well as the inner, the legalistic as well as the spiritual..." (AlAkiti, 2011, 573-574).

It is evident that with all his efforts and achievements al-Ghazali offered a great contribution in reviving the spiritual dimension of Islam, furnished and served it to the Muslim world. An important feature of al-Ghazali's approach is that his comprehensive discussions are addressed to various classes of people. When he discusses good deeds, he covers their various aspects, and he even goes to the smallest and subtle aspects of the issues which are seemingly insignificant to other people. He strives to fill in the gaps (mainly the inner or spiritual dimension) that he found were missing in his contemporary writings and teachings, going into the highest level of explanations, which are always mystical. However, unlike al-Hallaj (c. 858, 922 CE) and Ibn 'Arabi (1164/651240 CE), al-Ghazali does not go beyond the limits set by the Shari'ah. He sets limits to his discussions and avoids becoming entangled in very controversial issues, such as through offering purely esoteric interpretations which can be misunderstood by or mislead people. He is aware that his readers come from different classes of people, therefore, he devotes discussions that can include all of them. Consequently, different classes of people can find something for themselves in Ihya'. By doing this, they have alternatives to practise the teachings of Ihya' that are suitable to their religious or spiritual state.

Another unique approach of al-Ghazali is the way he uses personal experience, furnishes his discussions with rich sources, and offers various role models. He is keen to share what he gained through his spiritual journey in order to make others better (al-Ghazali 1967, 123; 2004, 82). In order to satisfy the mind and heart and different classes of readers, as well as to offer more additional proofs and to shed more insights and interpretations on the issues he discussed, alGhazali offers various additional sources beyond the Qur'anic verses and the sound Prophetic traditions (al-hadith al-sahih). These include weak Prophetic traditions, some Biblical references, reports from the Companions of the Prophet as well as other great scholars, mystics, philosophers and many others (Smith, 1983, Chap. 5, 67-81; Kukkonen, 2011; Zaqzud, 1993; Al-Akiti, 2009; Jules Janssens, 2011). To provide role models, he narrates various stories, reports, and experiences of different classes of Muslims. It can be said that by using various sources, he aimed to address 
not only Muslims but also non-Muslims, especially Christians. It can also be argued that he systematised "the code of the role model" in writings. Thus his views and teachings are not mere theoretical or imaginary concepts, but are indeed practical and have been practised previously.

\subsection{CONCLUSION}

Islam has yet to see another scholar like al-Ghazali whose work encompass various sciences and influenced countless minds in the Muslim and Western world. He scrutinised each and every major problem he saw in the Muslim world and after offering a careful critique, set to offer solutions. Al-Ghazali was one of the first Muslim jurists who introduced the consideration of a "public benefit" (maslahah) into Muslim jurisprudence (Frank Griffel, 2014). In the same regard, Montgomery Watt also acknowledges al-Ghazali's high status and considers him as "the leader in Islam's supreme encounter with Greek philosophy," from which Islamic theology attained its victory and in which philosophy, particularly Neoplatonism, "received a blow from which it did not recover" (Montgomery 2004, 13). It is true that few Muslim intellectuals claim that al-Ghazali left negative influences on thinking on developments in Muslim thought, such as on philosophy. However, if this is the case, then there would not be any Islamic civilisation after him. Nonetheless, Muslim world continued to lead in all sciences till mid seventeen century. D.B. MacDonald adds that al-Ghazali is indeed "the greatest, certainly the most sympathetic figure in the history of Islam, and the only teacher of the after-generations ever put by a Muslim on a level with the four great imams," (George F. McLean, 2002). Because he lived during a time of spiritual crisis in the Muslim world, his works are a product of that particular time (Fethullah Gulen, 2011a, 72). He established connections between seemingly clashing or opposing philosophies with Islamic theology and Sufism, reviewing them and reinterpreting them for the conditions of his age. His works mark a new stage where the intellect and heart are married in the path of spirituality. For instance, he mastered philosophy first before criticized it in order to Islamicize it (Kojiro Nakamura, 2008). After adapting philosophy to Islam or Islamicising philosophy, his greatest act was to bring the expectation of actions back in line with spirituality. Through this way, actions were expected to be done not only on a superficial basis or because of the rules and commands of religion and society, but done with a deeper understanding of the wisdom of each act.

By combining the strengths of the heart and mind, al-Ghazali laid the foundation of a new educational model which later produced many great scientists and scholars such as Ibn Tufail (1105-1185), Fakhr ad-Din ar-Razi,(1149-1209), Ibn al-Nafis (1213-1288), Ibn al-Khatib (13131374), Baha-ud-Din Naqshbandi (1318-1389) Ibn Khaldun (1332-1406) and many others.

Fethullah Gulen states that the world is in need of Islam and Islam is in need of representation (cited in Salih Yucel, 2011, 65-76). To truly understand what is meant by representation, the Muslim world needs more al-Ghazalis who have a thorough grasp on the problems of Muslims in this time. There is a need for those who practice the solutions before prescribing them. Al-Ghazali emerged as a reviver, an agent of renewal during the fifth century of Islam. He can also be called as 'the scholar of seekers'. His interpretation of philosophy and Sufism later inspired countless Muslim and non-Muslim scholars, and continue to inspire many more in the modern world until today.

Many aspects of al-Ghazali's life and teachings are still relevant to current Muslim society. Undoubtedly, most of his abiding spiritual insights are always relevant across the time because they are based on pure truths and ma'rifah that were revealed to him during his extensive seclusion. His three stages of life or spiritual journey can be taken as among the model for society in pursuing and disseminating the truth and in attaining higher spiritual level. Following al'Ghazali's stages of life, we should first prepared ourselves with various knowledge. In the second stage, we should focus on practicing the knowledge and purifying ourselves. In the third stage, we should share our experience and knowledge with the society.

Al-Ghazali has attained a great abiding success that no other Muslim scholar before or after him has ever achieved in different sciences. He was an extraordinary thinker and exceptional scholar of various disciplines of knowledge. Perhaps it can be claimed that he was not only 
successful in rediscovering the spiritual dimension of Islam and synthesising Sufism with the traditional Islam, but he is indeed the shining pearl of Islamic spirituality, the spirit or heart of Islam.

\section{References}

Al-Akiti, M. Afifi. (2009). "The Good, the Bad, and the Ugly of Falsafa: Al-Ghazali's Madnun, Tahafut and Maqasid with Particular Attention to their Falsafi Treatments of God's Knowledge of Temporal Events." In Y.T. Langermann (ed.). Avicenna and His Legacy: A Golden Age of Science and Philosophy, 51-100. Turnhout: Brepols.

Al-Akiti, M. Afifi. (2011). "On Celebrating the 900th Anniversary of al-Ghazali." The Muslim World. 101, no. 4 (2011): 573-580.

Albertini, Tamara. (2005). "Crisis and Certainty of Knowledge in al-Ghazali (1058-1111) and Descartes (1596-1650)." Philosophy East and West. 55, no. 1 (2005): 1-14.

Al-Ghazali. (1962). The Book of Knowledge. Translated by Nabih Amin Faris. New Delhi: Islamic Book Service, [Ihya' 1NF].

Al-Ghazali. (1967). Al-Munqidh min al-Dalal wa al-Muwassil ila dhi al- 'Izzah wa al-Jalal. Edited with introduction by Jamil Saliba and Kamil 'Ayyad. 7th ed. Bayrut: Dar al-Andalus, [Munqidh].

Al-Ghazali. (1980). Al-Mustazhiri: Being a Translation of Fada'ih al-Batiniyyah wa Fadail alMustazhiriyyah. Translated by Richard J. McCarthy. In Freedom and Fulfillment: An Annotated Translation of Al-Ghazali's al-Munqidh min al-Dalal and Other Relevant Works of al-Ghazali. 175-286. Boston: Twayne Publishers, [al-Mustazhiri].

Al-Ghazali. (1981). Al-Ghazzalis Mishkat al-Anwar ("The Niche of Lights"). Translated with introduction by W. H. T. Gairdner. New Delhi: Kitab Bhavan, , [The Niche].

Al-Ghazali. (1986). Ihya' 'Ulum al-Din. Edited by Zayn al-Din Abi al-Fadl 'Abd al-Rahim ibn alHusayn al-'Iraqi. 4 volumes. Bayrut: Dar al-Ma'rifah, [Ihya'].

Al-Ghazali. (1992). Letters of al-Ghazzali. Translated by Abdul Qayyum. New Delhi: Kitab Bhavan, [Letters Gh.].

Al-Ghazali. (1993). Revival of Religious Learnings: Imam Ghazzali's Ihya Ulum-id-Din. Translated by Fazl-ul-Karim. 4 volumes. Karachi: Darul-Ishaat, [Revival].

Al-Ghazali. (1997a). Al-Wajiz fi Fiqh al-Imam al-Shafi'i. Edited by 'Ali Mu'awwid and 'Adil 'Abd alMawjud. 2 vols. Bayrut: Dar al-Arqam, [al-Wajiz].

Al-Ghazali. (1997b). Al-Wasit fi al-Madhhab Edited by Ahmad Mahmud Ibrahim. 7 vols. Cairo: Dar al-Salam, [al-Wasit].

Al-Ghazali. (1999). The Foundations of the Articles of Faith: Being a Translation with Notes of the Kitab Qawa id al- 'Aqa'id of al-Ghazzali's Ihya' 'Ulum al-Din. Translated with notes by Nabih Amin Faris. Lahore: SH. Muhammad Ashraf, [Ihya' 2].

Al-Ghazali. (2000a). Maqasid al-Falasifah. Edited by Mahmud Bijou. Damascus, Matba'ah alDabbah, [Maqasid].

Al-Ghazali. (2000b). The Incoherence of the Philosophers: Tahafut al-Falasifah: A Parallel EnglishArabic Text. Translated, introduced and annotated by Michael E Marmura. 2nd ed. Provo, Utah: Brigham Young University Press, [The Incoherence].

Al-Ghazali. (2001a). Kimiya'-i-Sa 'adat (Alchemy of Eternal Bliss). Full English translation of the Persian original texts. Translated by Muhammad Asim Bilal. Revised by Munir Ahmad Mughal. Lahore- Pakistan: Kazi Publications, [Alchemy]. 
Al-Ghazali. (2001b). Kimiya'-i-Sa 'adat (Alchemy of Eternal Bliss). Full English translation of the Persian original texts. Translated by Muhammad Asim Bilal. Revised by Munir Ahmad Mughal. Lahore- Pakistan: Kazi Publications, [Alchemy].

Al-Ghazali. (2003a). Al-Arba 'in fi Usul al-Din fi al- 'Aqa'id wa Asrar al-'Ibadat wa al-Akhlaq. Edited by 'Abdullah al-Hamid 'Arwani and Muhammad Bashir al-Shaqfah. Dimashq: Dar al-Qalam, [Arba'in].

Al-Ghazali. (2003b). Al-Iqtisad fi al-I'tiqad. Edited by Insaf Ramadan. Damascus: Dar al-Qutaybah, [al-Iqtisad].

Al-Ghazali. (2004). Deliverance from Error and Attachment to the Lord of Might \& Majesty, in The Faith and Practice of al-Ghazali, 15-92. Translated by W. Montgomery Watt. Oxford: Oneworld Publications. First published in 1953, [Deliverance].

Al-Ghazali. (2010). Jalan Pintas Meraih Hidayah: 40 Prinsip Agama (Malay translation of alArba in fi Usul al-Din). Translated by Rojaya. Selangor: Pelima Media Sdn Bhd, [Jalan Pintas].

Anwarul-Haq, M. (1991). “The Soofi Practices of Moulana Muhammad Ilyas.” Awake. vol.4.

Faris, Nabih Amin. (1942). “Al-Ghazzāli’s Rules of Conduct.” The Muslim World. 32, no. 1 (1942): 43-50.

Griffel, Frank. (2009). Al-Ghazali’s Philosophical Theology. Oxford: Oxford University Press.

Griffel, Frank. (2014). “Al-Ghazali.” Stanford Encyclopedia of Philosophy. Retrieved from http://plato.stanford.edu/entries/al-ghazali/.

Gulen, Fethullah. (2008). Fasildan Fasila 3, Izmir: Nil Yayinlari.

Gulen, Fethullah. (2011a). Gunler Bahari Soluklarken. Izmir: Nil Yayinlari.

Gulen, Fethullah. (2011b). Kalbin Zumrut Tepeleri. Izmir: Nil Yayinlari.

Hourani, George F. (1984). “A Revised Chronology of Ghazali's Writings.” Journal of the American Oriental Society. 104, no. 2 (1984): 289-302.

Janssens, Jules. (2011). "Al-Ghazali between Philosophy (Falsafa) and Sufism (Tasawwuf): His Complex Attitude in the Marvels of the Heart ('Aja'ib al-Qalb) of the Ihya' 'Ulum al-Din." The Muslim World. 101, no. 4 (2011): 614-632.

Kukkonen, Taneli. (2011). "Al-Ghazali on Accidental Identity and the Attributes." The Muslim World. 101, no. 4 (2011): 658-679.

MacDonald, Duncan B. (1899) "The Life of Al-Ghazzali, with Especial Reference to His Religious Experience and Opinions.” Journal of the American Oriental Society. 20 (1899): 71-132.

McLean, George F. (2002). Editor's Introduction to Munqidh min al-Dalal. Retrieved from http://www.ghazali.org/books/md/IIA-02editor.htm.

Moad, Edward Omar. (2009). "Comparing Phases of Skepticism in al-Ghazali and Descartes: some First Meditations on Deliverance from Error.” Philosophy East and West. 59, no. 1 (2009): 88-101.

Mohamed, Yasien. (2011). "The Ethics of Education: Al-Isfahani's al-Dhari'a as a Source of Inspiration for al-Ghazali’s Mizan al-‘Amal.” The Muslim World. 101, no. 4 (2011): 633-657.

Nakamura, Kojiro. (2008). “Al-Ghazali, Abu Hamid.” Retrieved from http://www.ghazali.org/articles/gz1.htm.

Nursi, Said. (1996). The Letters. Translated by Sukran vahide. Istanbul: Sozler Publications.

Ormsby, Eric. (2008). Ghazali: The Revival of Islam. Oxford: Oneworld. 
Qayyum, Abdul. (1992). Preface and introduction to Letters of al-Ghazzali. By al-Ghazali, vii-19. Translated by Abdul Qayyum. New Delhi: Kitab Bhavan.

Quasem, Muhammad Abul. (1974). "Al-Ghazali's Theory of Devotional Acts.” Islamic Quarterly. 18, no. 3-4 (1974); 48-61.

Quasem, Muhammad Abul. (1978). The Ethics of al-Ghazali: A Composite Ethics in Islam. Monographs in Islamic Religion and Theology. Delmar, N.Y.: Caravan Books.

Rayan, Sobhi. (2004). “Al-Ghazali’s Method of Doubt.” Middle East Studies Association Bulletin. 38, no. 2 (2004): 162-173.

Sherif, Mohamed Ahmed. (1975). Ghazali's Theory of Virtue. Albany: State University of New York Press.

Smith, Margaret. (1983). Al-Ghazali the Mystic: A Study of the Life and Personality of Abu Hamid Muhammad al-Tusi al-Ghazali, Together with an Account of His Mystical Teaching and an Estimate of His Place in the History of Islamic Mysticism. Lahore: Hijra International Publishers.

'Umaruddin, M. (1996). The Ethical Philosophy of al-Ghazali, 1962. Revised edition. Delhi: Adam Publishers \& Distributers, 1996. Page reference are to the 1996 edition.

Watt, W. Montgomery. (1953). Introduction to The Faith and Practice of al-Ghazali, 9-14. Translated by W. Montgomery Watt. Oxford: Oneworld Publications, 2004. First published in.

Watt, W. Montgomery. (2004). Introduction to The Faith and Practice of al-Ghazali, 9-14. Translated by W. Montgomery Watt. Oxford: Oneworld Publications. First published in 1953.

Yucel, Salih. (2011). "Spiritual Role Models in Fethullah Gülen's Educational Philosophy." TAWARIKH: International Journal for Historical Studies. 3. no. 1 (2011), 65-76.

Zamir, Syed Rizwan. (2010). "Descartes and al-Ghazali: Doubt, Certitude and Light." Islamic Studies. 49, no. 2 (2010): 219-251.

Zaqzud, Mahmud Hamdi. (1993). Antara Falsafah Islam dan Falsafah Moden Barat: Suatu Perbandingan antara Al-Ghazali dan Descartes (Islamic Philosophy and Modern Western Philosophy: A Comparison Between al-Ghazali and Descartes), xiii-xvii. Translated by Mohd. Sulaiman Hj. Yasin. Kuala Lumpur: Dewan Bahasa dan Pustaka. 